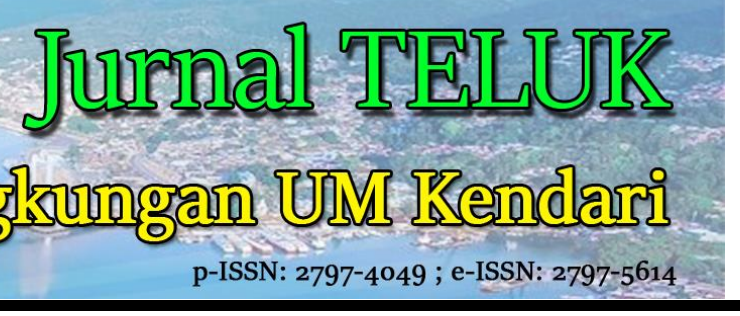

Artikel Penelitian

\title{
Perencanaan Desain Instalasi Pengolahan Air Limbah dengan Metode Biofilter Anaerob - Aerob
}

\author{
Neshart ${ }^{a}$, Rosdiana $^{a}$, Dwiprayogo Wibowo $^{a}$, Ahmad Syarif Sukri ${ }^{b, *}$ \\ ${ }^{a}$ Program Studi Teknik Lingkungan, Fakultas Teknik, Universitas Muhammadiyah Kendari - Jl. K.H. Ahmad Dahlan No. 10, Kendari 93117 - Sulawesi \\ Tenggara, Indonesia. \\ ${ }^{b}$ Jurusan Teknik Sipil, Fakultas Teknik Universitas Halu Oleo - Jl.HEA Mokodompit Kampus Baru UHO, Kendari 93231 - Sulawesi Tenggara, Indonesia.
}

\section{INFORMASI ARTIKEL}

Sejarah Artikel:

Diterima Redaksi: 2 Mei 2021

Revisi Akhir: 23 Mei 2021

Diterbitkan Online: 1 Juni 2021

\begin{tabular}{l} 
KATA KUNCI \\
\hline Processing, Wastewater, Biofilter \\
KORESPONDENSI \\
\hline Telepon: \\
E-mail: ahmad.syarif.sukri@uho.ac.id \\
\hline
\end{tabular}

\section{A $\quad$ B $\quad S \quad T \quad R A$ C $\mathbf{T}$}

\begin{abstract}
Planning design of wastewater treatment plant in a market is needed to improve the quality of water that will be discharged so it doesn't pollute the environment and the near. The goal of this study is to determine the discharge of wastewater will be treated and the design of treatment basin in the wet lods area of Mandonga Traditional Market. Result of wastewater is $7.88 \mathrm{~m}^{3} /$ day with a waste concentration of $\mathrm{pH}$ 7, BOD $64.2 \mathrm{mg} / \mathrm{day}$, and TSS $2.130 \mathrm{mg} / \mathrm{day}$. Wet Lods Wastewater Treatment Plant in Mandonga Traditional Market has 6 compartments such as a control tub with the fine filter addition which has a volume of $0.072 \mathrm{~m}^{3} /$ day, the initial settling tank has a volume of $1 \mathrm{~m}^{3} /$ day, anaerobic biofilter has a volume of $1.83 \mathrm{~m}^{3} /$ day, aerobic tubs have a volume of $0.42 \mathrm{~m}^{3} /$ day, the final settling tank I has a volume of $1.1 \mathrm{~m}^{3} /$ day and the final settling tub II has a volume of $1.1 \mathrm{~m}^{3} /$ day.
\end{abstract}

\section{PENDAHULUAN}

Kendari sebagai Ibu Kota Provinsi Sulawesi Tenggara merupakan sebuah kota yang berkembang. Perkembangannya ditandai dengan laju pertumbuhan penduduk, tercatat dari tahun 2010 hingga 2016 peningkatan jumlah penduduk sebesar 3,54\% atau 22.567 jiwa penduduk per Tahun (BPS Sultra, 2020). Bertumbuhnya jumlah penduduk dalam suatu perkotaan tentu berdampak pada meningkatnya aktivitas perekonomian masyarakat misalnya kegiatan perdagangan. Setiap aktivitas yang dilakukan manusia akan menghasilkan limbah, limbah ini dalam skala kecil tidak akan menimbulkan masalah karena alam memiliki kemampuan untuk menguraikan kembali komponen komponen yang terkandung dalam limbah, namun bila terakumulasi dalam skala besar, akan timbul permasalahan yang dapat mengganggu keseimbangan lingkungan hidup (Mega dkk., 2013). Sumber air limbah dapat berasal dari kawasan domestik dan nondomestik. Sumber air limbah domestik adalah rumah susun, penginapan, asrama, pelayanan kesehatan, lembaga pendidikan, perkantoran, perniagaan, pasar, rumah makan, balai pertemuan, arena rekreasi, permukiman, industri, IPAL kawasan, IPAL permukiman, IPAL perkotaan, pelabuhan, bandara, stasiun kereta api, terminal dan lembaga kemasyarakatan (Permen LHK, 2016).

Pasar mempunyai potensi yang cukup besar untuk menghasilkan air limbah domestik, sementara pengolahan air limbah merupakan permasalahan tersendiri yang harus diatasi. Untuk kawasan pasar yang menjadi objek penelitian adalah area lods basah yang terletak di kawasan Pasar Tradisional Mandonga. Area ini menyediakan 120 lapak untuk pedagang, namun baru terisi 72 lapak dimana tempat tersebut khusus menjual berbagai macam daging hewani mulai dari ikan, udang, kepiting, cumi cumi, ayam, sapi dan lain lain.

Aktivitas lods basah Pasar Tradisional Mandonga tidak terlepas dari penggunaan air bersih yang menjadi sumber utama terbentuknya air limbah. Berdasarkan pengamatan di lapangan, air limbah lods basah biasanya berasal dari kegiatan mencuci dagangan, membersihkan meja lapak, menyiram lantai serta membersihkan peralatan. Aktivitas tersebut kemudian menghasilkan air limbah dimana air limbah mengalir melalui drainase kecil dalam lods menuju sebuah saluran pipa pembuangan yang akan dibuang ke drainase yang ada di luar gedung pasar, dari drainase tersebut mengalir menuju ke bak penampungan air limbah, namun kemudian air limbah tersebut 
mengalir langsung menuju sungai Mandonga tanpa dilakukan pengolahan terlebih dahulu.

Berdasarkan aturan yang dikeluarkan oleh Permen LHK Nomor P.68/Menlhk/Setjen/Kum.1/8/2016 bahwa air limbah harus diolah terlebih dahulu agar aman dibuang ke lingkungan sesuai dengan parameter $\mathrm{pH}, \mathrm{BOD}, \mathrm{COD}$, TSS, Minyak dan Lemak, Amoniak, Total coliform, dan Debit.

\section{METODOLOGI}

\subsection{Tempat dan Waktu Penelitian}

Penelitian ini direncanakan dan dilaksanakan di area lods basah Pasar Tradisional Mandonga Kota Kendari pada bulan Oktober 2019 - Mei 2020.

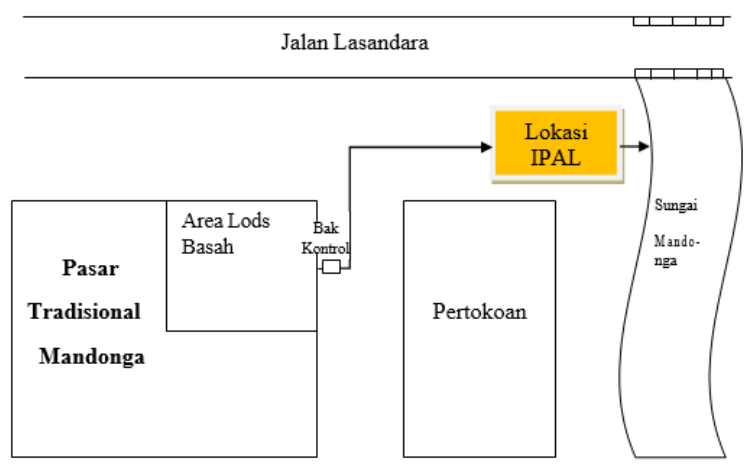

Gambar 1. Denah lokasi penelitan

\subsection{Populasi dan Sampel}

Populasi dari penelitian ini adalah semua air limbah yang dihasilkan para pedagang lods basah pasar tradisional Mandonga. Sedangkan sampel pada penelitian ini adalah air limbah yang berada di inlet dan outlet pipa pembuangan sebelum masuk ke drainase di luar pasar.

\subsection{Prosedur Kerja}

\subsubsection{Persiapan sampel}

Pengambilan sampel pada jam puncak aktivitas yaitu pukul 10.00 , botol a sebanyak $600 \mathrm{~mL}$ air limbah diambil di inlet dan $600 \mathrm{~mL}$ botol b diambil di outlet pipa pembuangan air limbah lods basah, masing masing botol ditutup kain hitam guna menghindari kontak langsung dengan cahaya (SNI 6989.59: 2008).

\subsubsection{Perhitungan debit air limbah}

Perhitungan debit air limbah didasarkan pada penggunaan air bersih pasar tersebut (Said dkk., 2019). Jumlah penggunaan air bersih untuk pasar tradisional adalah 60 liter per orang per hari. Untuk memperkirakan jumlah air limbah domestik untuk tiap kegiatan usaha dapat dilakukan dengan mengacu kepada standar pemakaian air bersih (Persamaan 1) untuk berbagai kegiatan (Noerbambang dkk., 1986).

$$
Q \text { air limbah }=Q \text { air bersih }
$$

\subsubsection{Analisis karakteristik air limbah}

\section{Analisis $\mathrm{pH}$}

Analasis $\mathrm{pH}$ dilakukan secara mandiri, yaitu menggunakan kertas $\mathrm{pH}$ yang dicelup ke dalam dua botol sampel air limbah (inlet dan outlet), kemudian diangkat dan didiamkan beberapa detik. Setelah itu di amati berdasarkan perubahan warna pada kertas yang menunjukkan angka tingkat asam basah pada air limbah.

\section{Analisis BOD (SNI-6989-72_2009)}

Diukur $1000 \mathrm{~mL}$ contoh/sampel secara duplo dab masukkan ke dalam gelas piala $2000 \mathrm{~mL}$. Apabila contoh/sampel bersifat asam atau basa, netralkan dengan $\mathrm{NaOH} 0,1 \mathrm{~N}$ atau $\mathrm{H}_{2} \mathrm{SO}_{4} 0,1 \mathrm{~N}$ sampai antara $\mathrm{pH}, 6,5-7,5$. Apabila contoh/sampel tidak mengandung mikroorganisme pengurai tambahkan $1000 \mathrm{~mL}$ larutan pengencer sehingga pengenceran 2 kali. Apabila contoh uji diperkirakan mempunyai kadar BOD lebih dari $6 \mathrm{mg} / \mathrm{L}$, encerkan contoh/sampel dengan larutan pengencer sehingga kadar BOD antara $3-6 \mathrm{mg} / \mathrm{L}$. Aerasi dengan aerator selama 1 jam sampai oksigen terlarut $7-8 \mathrm{mg} / \mathrm{L}$. Dimasukkan ke dalam 2 buah botol winkler $300 \mathrm{~mL}$, sampai meluap. Kemudian tutup botol winkler, hindarkan terjadi turbulensi dengan gelembung udara selama pengisian. Dimasukkan 1 botol winkler yang berisi sampel ke dalam inkubator bersuhu $20^{\circ} \mathrm{C}$ dieramkan hingga 5 hari.

Dimasukkan $1 \mathrm{~mL}$ larutan alkali iodide azida, tutup botol winkler dan homogenkan. Ditunggu selama 10 menit sampai air sampel bereaksi dengan $\mathrm{MnSO}_{4}$ dan alkali iodide azida sehingga membentuk endapan. Dimasukkan $10 \mathrm{~mL}$ larutan asam sulfat, tutup botol winkler dan dihomogenkan hingga berwarna kuning bening transparan dan butiran butiran hitam yang melayang dalam larutan sampai hilang. Pipet $50 \mathrm{~mL}$ larutan sampel dalam botol winkler ke gelas erlenmeyer. Ditambahkan 1 tetes indikator amilum hingga larutan berubah menjadi biru gelap. Dilakukan proses titrasi dengan larutan thiosulfate hingga berwarna putih benang, catat kebutuhan larutan thiosulfate. Setelah 5 hari diperiksa kadar oksigen terlarut 5 hari larutan sampel pada botol winkler yang telah dieramkan (cara pengukuran sama seperti pengukuran kadar oksigen terlarut 0 hari). BOD diuji menggunakan BOD meter. Perhitungan kadar BOD air limbah menggunakan rumus persamaan (2):

$$
\begin{aligned}
& D O(m g / L)=\frac{a \times N \times 8 \times 1000}{V} \\
& \mathrm{a}=\text { volume thiosulfate }(\mathrm{mL}) \\
& \mathrm{N}=\text { normalitas thiosulfate }(\mathrm{mL}) \\
& \mathrm{V}=\text { volume sampel }(\mathrm{mL}) \\
& \mathrm{P}=\text { derajat pengenceran sampel } \\
& B O D_{5} 20^{0}=\frac{D O_{0}-D O_{5}}{P}
\end{aligned}
$$

3. Analisis TSS (SNI-06-6989.3-2004)

Kertas saring bersama dengan cawan porselen dimasukkan ke dalam oven suhu $105^{\circ} \mathrm{C}$ selama $1 \mathrm{jam}$. Setelah melalui proses pengeringan, kertas saring bersama dengan cawan porselen diukur beratnya menggunakan timbangan dan dipersiapkan kertas saring ke peralatan vakum. Dilakukan penyaringan dengan peralatan vakum. Basahi saringan dengan sedikit air suling. Diaduk sampel dengan pengaduk magnetic stirrer untuk memperoleh sampel yang lebih homogen dan pipet sampel dengan volume tertentu, pada waktu sampel diaduk dengan pengaduk magnetic stirrer. 
Cuci kertas saring dengan $3 \times 10 \mathrm{~mL}$ air suling, biarkan kering sempurna, dan lanjutkan penyaringan dengan vakum selama 3 menit agar diperoleh penyaringan sempurna. Sampel dengan padatan terlarut tinggi memerlukan pencucian tambahan. Dipindahkan kertas saring secara hati hati dari peralatan penyaring dan pindahkan ke wadah cawan porselen. Dikeringkan dalam oven setidaknya selama 1 jam pada suhu $103^{\circ} \mathrm{C}$ sampai dengan $105^{\circ} \mathrm{C}$, dinginkan dalam deksikator untuk menyeimbangkan sauhu dan timbang.

$$
\text { mg TSS per liter }=\frac{(A-B) \times 1000}{\text { Volume sampel }(m L)}
$$

$$
\begin{aligned}
& \text { Keterangan: } \\
& \mathrm{A}=\text { berat kertas saring + residu kering }+ \text { cawan porselen }(\mathrm{g}) \\
& \mathrm{B}=\text { berat kertas saring }+ \text { cawan porselen }(\mathrm{g})
\end{aligned}
$$

\section{Desain IPAL}

Setelah mendapatkan hasil analisis dari $\mathrm{pH}$, BOD dan TSS maka desain IPAL dapat direncanakan merujuk pada perencanaan desain pengolahan air limbah metode biofilter anaerob aerob (Said, 2017) dapat dilihat pada Gambar 2.

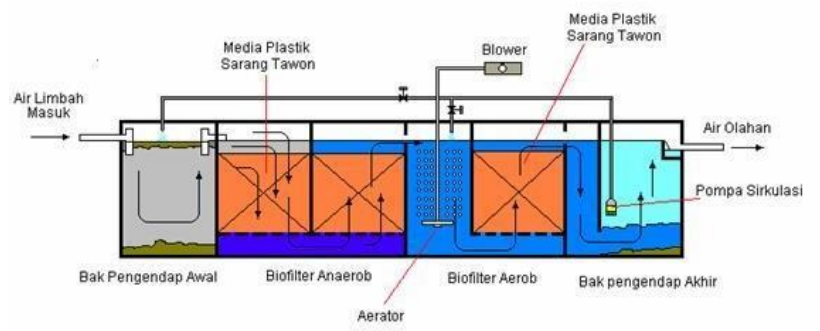

Gambar 2. Proses Pengolahan Air Limbah Dengan Media Biofilter Anaerob-Aerob (Said, 2017)

\section{HASIL DAN PEMBAHASAN}

\subsection{Gambaran Umum Lokasi Penelitian}

Pasar tradisional merupakan tempat bertemunya penjual dan pembeli serta ditandai dengan adanya transaksi penjual pembeli secara langsung, bangunan biasanya terdiri dari kios-kios atau gerai, lods dan dasaran terbuka yang dibuka oleh penjual maupun suatu pengelola pasar. Pasar tradisional Mandonga merupakan salah satu pasar tradisional yang berada di kota Kendari. Letaknya berdampingan dengan pasar Korem di Mandonga. Tepat dibelakang Mall Mandonga, jalan Lasandara Kelurahan Korumba, Kecamatan Mandonga.

Berdasarkan informasi yang didapat dari pihak pengelola bahwa pasar ini berada di naungan PT. Kurnia, dan ditahun 2020 berusia sekitar 18 tahun dengan masa kontrak 20 tahun sebelum dikembalikan pengelolaannya ke pemerintah daerah. Bangunannya terdiri dari dua lantai, yang pembagian lodsnya cukup semrawut. Di pasar ini terdapat sebuah area yang diberi nama lods basah, masyarakat umum mengenalnya dengan pasar basah. Lods basah menyediakan 120 lapak bagi para pedagang, namun baru terisi 72 lapak (Observasi, 2019).

Lods basah menjadi pusat aktivitas penjualan aneka daging hewani di pasar tradisional Mandonga. Di dalam setiap aktivitasnya, lods basah cukup banyak menggunakan air bersih, berdasarkan data di lapangan penggunaan air bersih per harinya yaitu 3-4 tower dengan volume per tower 1.200 liter. Banyaknya penggunaan air tersebut maka dapat membentuk air limbah. Hasil dari pantauan di lapangan menunjukkan kurangnya pengolahan air limbah dari lods basah pasar tradisional Mandonga. Hal ini dapat dilihat ketika berada di luar pasar, air limbah lods basah dibuang begitu saja ke drainase sehingga mencemari lingkungan sekitar pasar serta sungai yang menjadi titik akhir tempat pembuangan air limbah tersebut. Untuk studi kasus area lods basah pasar tradisional Mandonga menghasilkan air limbah Tabel 1.

Tabel 1. Air Limbah Los Basah Pasar Tradisional Mandonga

\begin{tabular}{ll}
\hline Sumber pengguna & Jenis dan Kegiatan \\
\hline Pelayanan kebersihan & - Proses pembersihan area \\
& - Proses penyiraman \\
Pedagang & Proses pembersihan sisik dan isi \\
Ikan dan hewan hewan & perut \\
laut lain seperti (udang, & - Proses penyimpanan (ikan yang \\
kepiting, cumi cumi, dll & disimpan dalam wadah dan \\
& diambil ketika ada pembeli) \\
& - Proses penyiraman \\
& - Proses pembersihan ayam \\
& - Ceceran darah \\
- & Membersihkan meja lapak, alat \\
Ayam & potong, dll \\
& - Membersihkan meja lapak, alat \\
& potong, dll \\
& - Daging tidak disiram karena \\
& dapat merusak kualitas daging \\
\hline
\end{tabular}

\subsection{Hasil Kajian Desain IPAL}

1. Penggunaan Air bersih

Data penggunaan air bersih diperlukan untuk mengetahui jumlah debit air limbah yang di hasilkan dari lods basah Pasar Tradisional Mandonga. Berdasarkan data yang diperoleh dari pihak pengelola pasar tradisional Mandonga bahwa penggunaan air bersih yang digunakan untuk 72 lapak di lods basah dalam sehari menghabiskan 4 tower air dengan volume per tower 1.200 Liter.

\section{Karakteristik Air Limbah}

Analisa karakteristik air limbah dilakukan untuk mengetahui sifat dan karakteristik air limbah di lods basah Pasar Tradisional Mandonga. Analisa karakteristik ini dilakukan berdasarkan Permen LHK Nomor P.68/Menlhk/Setjen/Kum.1/8/2016 tentang baku mutu air limbah domestik, yaitu terhadap parameter $\mathrm{pH}, \mathrm{BOD}$, dan TSS. Berikut ini hasil dari uji pengambilan sampel air limbah lods basah pasar tradisional Mandonga diambil pada tanggal 13, 16, dan 17 April 2020 dapat dilihat pada Tabel 2 .

Nilai $\mathrm{pH}$ air yang ada pada tabel 4.2 mengekpresikan kondisi keasaman (konsentrasi ion hidrogen) air limbah. Skala pH berkisar antara 1-14; kisaran nilai pH 1-7 termasuk kondisi asam, $\mathrm{pH}$ 7-14 termasuk kondisi basa, dan $\mathrm{pH} 7$ adalah kondisi netral.

Adapun faktor-faktor yang mempengaruhi kadar BOD air limbah diakibatkan oleh kandungan serta jenis bahan organik yang ada di dalam air, suhu, densitas plankton, oksigen terlarut, nilai $\mathrm{pH}$, dan keberadaan mikroba. Apabila kandungan BOD tinggi, maka akan mengakibatkan penyusutan oksigen terlarut melalui proses penguraian bahan organik pada kondisi aerobik 
dan penurunan nilai $\mathrm{pH}$ dalam suatu perairan. Sedangkan untuk TSS sangat berkaitan erat dengan kekeruhan pada air salah satunya memang disebabkan oleh adanya kandungan zat padat tersuspensi. Zat tersuspensi yang ada di dalam air terdiri dari berbagai macam zat, misalnya pasir halus, tanah liat, dan lumpur alami yang merupakan bahan-bahan anorganik atau dapat pula berupa bahan-bahan organik yang melayang-layang di dalam air.

Berdasarkan hasil yang diperoleh bahwa parameter $\mathrm{pH}$ air limbah lods basah dengan jumlah 7 masih sesuai dengan baku mutu yang diperbolehkan Permen LHK Nomor P.68/Menlhk/Setjen/Kum.1/8/2016 yaitu 6 - 9, dan untuk parameter BOD air limbah lods basah pasar tradisional Mandonga sebesar $64,2 \mathrm{mg} / \mathrm{L}$ melebihi baku mutu yang ditetapkan Permen LHK Nomor P.68/Menlhk/Setjen/Kum.1/8/2016 yaitu sebesar $30 \mathrm{mg} / \mathrm{L}$. Demikian juga TSS yaitu sebesar $2.130 \mathrm{mg} / \mathrm{L}$, sedangkan baku mutu yang diperbolehkan Permen LHK Nomor P.68/Menlhk/Setjen/Kum.1/8/2016 hanya sebesar $30 \mathrm{mg} / \mathrm{L}$.

Tabel 2. Karakteristik Air Limbah Lods Basah Pasar Tradisional Mandonga

\begin{tabular}{|c|c|c|c|c|c|c|c|c|c|}
\hline \multirow{2}{*}{ Parameter } & \multirow{2}{*}{ Satuan } & \multicolumn{2}{|c|}{ Hari I } & \multicolumn{2}{|c|}{ Hari II } & \multicolumn{2}{|c|}{ Hari III } & \multirow{2}{*}{ Rata-rata } & \multirow{2}{*}{ Baku Mutu } \\
\hline & & In & Out & In & Out & In & Out & & \\
\hline $\mathrm{pH}$ & - & 7 & 7 & 8 & 8 & 7 & 7 & 7,33 & $6-9$ \\
\hline BOD & $\mathrm{mg} / \mathrm{L}$ & 56,10 & 72,30 & 55,20 & 73,20 & 58,60 & 69,80 & 64,2 & 30 \\
\hline TSS & $\mathrm{mg} / \mathrm{L}$ & 2.320 & 1.940 & 2.250 & 2.010 & 2.380 & 2.000 & $\begin{array}{c}2.13 \\
0\end{array}$ & 30 \\
\hline
\end{tabular}

3. Debit Air Limbah Lods Basah Pasar Tradisional Mandonga Berdasarkan data dari pihak pengelola pasar jumlah lapak yang ada di lods basah adalah 120 lapak dan baru terisi 72 lapak dengan penggunaan air bersih dalam satu hari sebesar 4.800 Liter. Perhitungan debit air limbah berdasarkan penggunaan air bersih dapat dilihat pada Tabel 3 berikut.

Tabel 3. Hasil perhitungan debit air limbah lods basah

\begin{tabular}{llll}
\hline Ketrangan & & Nilai \\
\hline $\begin{array}{l}\text { Penggunaan air bersih per } \\
\text { lapak }\end{array}$ & $66,67 \mathrm{~L} /$ lapak/hari \\
$\begin{array}{l}\text { Volume yang diperlukan } \\
\text { sebanyak 120 lapak }\end{array}$ & $8000 \mathrm{~L} / \mathrm{hari} \approx 8 \mathrm{~m}^{3} \cdot \mathrm{h}^{-1}$ & \\
$\begin{array}{l}\text { Debit air limbah } \\
\end{array}$ & $\begin{array}{lll}7,88 \quad \mathrm{~m}^{3} \cdot \mathrm{h}^{-1} \quad \text { atau } \\
\end{array}$ & $0,0000912037 \mathrm{~m}^{3} / \mathrm{det}$ & \\
\hline
\end{tabular}

Maka debit air limbah dihitung berdasarkan persamaan kontinuitas air yaitu:

$Z 1+Q 1=Z 2+Q 2+H f($ Persamaan Bernoulli $)(5)$

Diperoleh 7,88 $\mathrm{m}^{3} \cdot \mathrm{h}^{-1}$ atau $0,0000912037 \mathrm{~m}^{3} /$ det. Berdasarkan hasil di atas maka debit air limbah yang dihasilkan area lods basah Pasar Tradisional Mandonga adalah 7,88 $\mathrm{m}^{3} \cdot \mathrm{h}^{-1}$.

\section{Perhitungan Desain IPAL}

Kapasitas desain yang diharapkan adalah sebagai berikut :

Kapasitas pengolahan $\quad=7,88 \mathrm{~m}^{3} \cdot \mathrm{h}^{-1}=0,33 \mathrm{~m}^{3} / \mathrm{jam}$

$=5,55 \mathrm{~L} / \mathrm{menit}$

BOD air limbah $\quad=64,2 \mathrm{mg} / \mathrm{L}$

TSS air limbah $\quad=2.130 \mathrm{mg} / \mathrm{L}$

a) Bak Kontrol

Efisiensi bak kontrol dengan pemasangan screen halus dapat dilihat pada Tabel 4.

Tabel 4. Jumlah pengurangan kadar TSS di bak kontrol dengan pemasangan saringan halus (fine screen)

\begin{tabular}{cccc}
\hline $\begin{array}{c}\text { TSS Masuk } \\
(\mathbf{m g} / \mathbf{L})\end{array}$ & $\begin{array}{c}\text { Efisiensi } \\
(\%)\end{array}$ & $\begin{array}{c}\text { TSS keluar } \\
(\mathbf{m g} / \mathbf{L})\end{array}$ & $\begin{array}{c}\text { Ukuran celah } \\
\text { saringan } \\
(\mathbf{m m})\end{array}$ \\
\hline 2,130 & 30 & 1,491 & 3 \\
\hline
\end{tabular}

Efisiensi penggunaan bak kontrol menggunakan saringan halus (fine screen) terhadap penurunan TSS sebesar $15-30 \%$ (Pankratz, 2017). Ukuran celah untuk saringan halus (fine screen) kurang dari $6 \mathrm{~mm}$. Penggunaan saringan halus pada bak kontrol juga dimaksudkan agar meminimalisir terjadinya penumpukkan material material kecil yang dapat menghambat laju air ketika mengalir dari pipa bak kontrol menuju bak pengendap awal. Menurut peraturan Menteri PUPR No. 04 Tahun 2017 luas permukaan bak kontrol adalah $50 \mathrm{~cm} \times 50 \mathrm{~cm}$, dan kedalaman 40 - $60 \mathrm{~cm}$ yang disesuaikan dengan kebutuhan kemiringan pipa persil yang masuk, maka desain bak kontrol dapat dilihat pada persamaan (6).

Volume efektif $=0,50 \mathrm{~m} \times 0,50 \mathrm{~m} \times 0,40 \mathrm{~m}=0,1 \mathrm{~m}^{3}$

b) Bak Pengendap Awal Efisiensi bak pengendap awal dapat dilihat pada Tabel 5.

Tabel 5. Jumlah pengurangan kadar BOD dan TSS di bak pengendap awal

\begin{tabular}{cccccc}
\hline $\begin{array}{c}\text { BOD } \\
\text { masuk } \\
(\mathbf{m g} / \mathbf{L})\end{array}$ & $\begin{array}{c}\text { Efisiensi } \\
\text { pengurangan } \\
\text { BOD }(\%)\end{array}$ & $\begin{array}{c}\text { BOD } \\
\text { keluar } \\
(\mathbf{m g} / \mathbf{L})\end{array}$ & $\begin{array}{c}\text { TSS } \\
\text { masuk } \\
(\mathbf{m g} / \mathbf{L})\end{array}$ & $\begin{array}{c}\text { Efisiensi } \\
\text { pengurangan } \\
\text { TSS }(\%)\end{array}$ & $\begin{array}{c}\text { TSS } \\
\text { keluar } \\
(\mathbf{m g} / \mathbf{L})\end{array}$ \\
\hline 64,2 & 40 & 25,68 & 1.491 & 60 & 596,4 \\
\hline
\end{tabular}

Efisiensi bak pengendap awal terhadap penurunan BOD sebesar $40 \%$ dan TSS sebesar $60 \%$. Diketahui debit limbah 7,88 $\mathrm{m}^{3} \cdot \mathrm{h}^{-1}$, waktu tinggal dalam bak 5 jam, maka data perhitungan dapat dilihat pada Tabel 6 .

Tabel 6. Desain dimensi bak pengendap awal

\begin{tabular}{cc}
\hline Keterangan & $\begin{array}{c}\text { Nilai } \\
\text { perhitungan }\end{array}$ \\
\hline Volume Bak & $1,7 \mathrm{~m}^{3} \cdot \mathrm{h}^{-1}$ \\
Dimensi bak & $0,55 \mathrm{~m}$ \\
Rata-rata waktu tinggal & $5,15 \mathrm{jam}$ \\
Beban permukaan rata-rata & $4,8 \mathrm{~m} \cdot \mathrm{hari}$ \\
\hline
\end{tabular}

c) Biofilter anaerob

Efisiensi bak pengendap awal terhadap penurunan kadar BOD sebesar $80 \%$ dan TSS sebesar 60\% dapat dilihat pada Tabel 7. 
Tabel 7. Jumlah pengurangan kadar BOD dan TSS di bak biofilter anaerob

\begin{tabular}{cccccc}
\hline $\begin{array}{c}\text { BOD } \\
\text { masuk } \\
(\mathbf{m g} / \mathbf{L})\end{array}$ & $\begin{array}{c}\text { Efisiensi } \\
\text { pengurangan } \\
\text { BOD }(\%)\end{array}$ & $\begin{array}{c}\text { BOD } \\
\text { keluar } \\
(\mathbf{m g} / \mathbf{L})\end{array}$ & $\begin{array}{c}\text { TSS } \\
\text { masuk } \\
(\mathbf{m g} / \mathbf{L})\end{array}$ & $\begin{array}{c}\text { Efisiensi } \\
\text { pengurangan } \\
\text { TSS }(\%)\end{array}$ & $\begin{array}{c}\text { TSS } \\
\text { keluar } \\
(\mathbf{m g} / \mathbf{L})\end{array}$ \\
\hline 25,68 & 80 & 5,14 & 596,4 & 60 & 239 \\
\hline
\end{tabular}

Untuk pengolahan air dengan proses biofilter standar, beban BOD per volume media adalah $0,4-4,7 \mathrm{~kg} \mathrm{BOD} / \mathrm{m}^{3}$.hari. ditetapkan beban BOD yang digunakan $=0,4 \mathrm{~kg}$ $\mathrm{BOD} / \mathrm{m}^{3}$.hari, maka rangkuman perhitungan disajikan dalam Tabel 8.

Tabel 8. Hasil perhitungan reaktor biofilter anaerob

\begin{tabular}{ll}
\hline \multicolumn{1}{c}{ Ketrangan } & Nilai Perhitungan \\
\hline Beban BOD dalam air limbah & $0,2 \mathrm{~kg} / \mathrm{hari}$ \\
Volume yang diperlukan & $0,5 \mathrm{~m}^{3}$ \\
Volume media $60 \%$ & $0,83 \mathrm{~m}^{3}$ \\
Waktu tinggal dalam reaktor anaerob & $2,5 \mathrm{jam}$ \\
Dimensi bak biofilter anaerob & $1 \mathrm{~m} \times 1 \mathrm{~m} \times 0,83 \mathrm{~m}$ \\
Cek waktu tinggal rata-rata & $2,5 \mathrm{jam}$ \\
Tinggi bed media pembiakkan & $0,6 \mathrm{~m}$ \\
mikroba & \\
Tinggi air di atas bed media & $0,2 \mathrm{~m}$ \\
Volume total media biofilter anaerob & $0,5 \mathrm{~m}^{3}$ \\
BOD loading per volume media & $0,4 \mathrm{~kg} \mathrm{BOD} / \mathrm{m}^{3}$ \\
\hline
\end{tabular}

d) Biofilter aerob

Untuk efisiensi bak biofilter aerob dapat dilihat pada Tabel 9 sebagai berikut.

Tabel 9. Jumlah pengurangan kadar BOD dan TSS di bak biofilter aerob

\begin{tabular}{cccccc}
\hline $\begin{array}{c}\text { BOD } \\
\text { masuk } \\
(\mathbf{m g} / \mathrm{L})\end{array}$ & $\begin{array}{c}\text { Efisiensi } \\
\text { pengurangan } \\
\text { BOD }(\%)\end{array}$ & $\begin{array}{c}\text { BOD } \\
\text { keluar } \\
(\mathbf{m g} / \mathbf{L})\end{array}$ & $\begin{array}{c}\text { TSS } \\
\text { masuk } \\
(\mathbf{m g} / \mathbf{L})\end{array}$ & $\begin{array}{c}\text { Efisiensi } \\
\text { pengurangan } \\
\text { TSS }(\%)\end{array}$ & $\begin{array}{c}\text { TSS } \\
\text { keluar } \\
(\mathbf{m g} / \mathbf{L})\end{array}$ \\
\hline 5,14 & 60 & 2,1 & 239 & 50 & 119,5 \\
\hline
\end{tabular}

Efisiensi bak biofilter aerob terhadap penurunan kadar BOD sebesar 60\% dan TSS sebesar 50\%, maka dapat dilihat pada Tabel 10 .

Tabel 10. Hasil perhitungan reaktor biofilter aerob

\begin{tabular}{ll}
\hline Ketrangan & Nilai Perhitungan \\
\hline Beban BOD dalam air limbah & $0,04 \mathrm{~kg} / \mathrm{hari}$ \\
Beban BOD per volume media & $0,4 \mathrm{~kg} / \mathrm{m}^{3}$. hari \\
Volume yang diperlukan & $0,1 \mathrm{~m}^{3}$ \\
Volume media 40\% & $0,25 \mathrm{~m}^{3}$ \\
Ruang aerasi & $0,3 \mathrm{~m} \times 1 \mathrm{~m} \times 0,23 \mathrm{~m}$ \\
Ruang bed media & $0,5 \mathrm{~m} \times 1 \mathrm{~m} \times 0,3 \mathrm{~m}$ \\
Efektif media biofilter aerob & $0,8 \mathrm{~m} \times 0,53 \mathrm{~m} \times 0,6 \mathrm{~m}$ \\
Cek waktu tinggal rata-rata & $1 \mathrm{jam}$ \\
Tinggi bed media biofilter & $0,6 \mathrm{~m}$ \\
Volume total media biofilter aerob & $0,09 \mathrm{~m}$ \\
BOD loading per volume media & $0,4 \mathrm{~kg} \mathrm{BOD} / \mathrm{m}^{3}$ \\
\hline
\end{tabular}

e) Bak Pengendap Akhir I

Efisiensi bak pengendap akhir I dapat dilihat pada Tabel 11 sebagai berikut.
Tabel 11. Jumlah pengurangan kadar BOD dan TSS di bak pengendap akhir I

\begin{tabular}{lcrlcr}
\hline $\begin{array}{l}\text { BOD } \\
\text { masuk } \\
(\mathbf{m g} / \mathbf{L})\end{array}$ & $\begin{array}{c}\text { Efisiensi } \\
\text { pengurangan keluar } \\
\text { BOD }(\%)\end{array}$ & $\begin{array}{c}\text { BOD } \\
(\mathbf{m g} / \mathbf{L})\end{array}$ & $\begin{array}{c}\text { TSS } \\
\text { masuk } / \mathbf{L})\end{array}$ & $\begin{array}{c}\text { Efisiensi } \\
\text { pengurangan } \\
\text { TSS }(\%)\end{array}$ & $\begin{array}{c}\text { TSS } \\
(\mathbf{m g} / \mathbf{L})\end{array}$ \\
\hline 2,1 & 50 & 1,05 & 119,5 & 50 & 59,75 \\
\hline
\end{tabular}

Efisiensi bak pengendap terhadap penurunan kadar BOD sebesar 50\% dan TSS sebesar 50\%, sehingga diperoleh perhitungannya disajikan pada Tabel 12 .

Tabel 12. Hasil perhitungan bak pengendap akhir I

\begin{tabular}{cll}
\hline No. & Ketrangan & Nilai Perhitungan \\
\hline 1 & Debit air limbah & $7,88 \mathrm{~m}^{3}$ \\
2 & Waktu tinggal dalam bak & $5 \mathrm{jam}$ \\
3 & Volume bak yang diperlukan & $1,7 \mathrm{~m}^{3}$ \\
4 & Dimensi bak pengendap akhir I & $1,7 \mathrm{~m} \times 1 \mathrm{~m} \times 1 \mathrm{~m}$ \\
5 & Tinggi ruang bebas & $0,55 \mathrm{~m}$ \\
6 & Volume efektif & $1,7 \mathrm{~m}^{3}$ \\
7 & Cek waktu tinggal rata-rata & $5 \mathrm{jam}$ \\
8 & Beban permukaan rata-rata & $4,8 \mathrm{~m} \cdot$ hari \\
\hline
\end{tabular}

f) Bak Pengendap Akhir II

Efisiensi bak pengendap akhir II dapat dilihat pada Tabel 13 sebagai berikut :

Tabel 13. Jumlah pengurangan kadar BOD dan TSS di bak pengendap akhir II

\begin{tabular}{cccccc}
\hline $\begin{array}{c}\text { BOD } \\
\text { masuk } \\
(\mathbf{m g} / \mathrm{L})\end{array}$ & $\begin{array}{c}\text { Efisiensi } \\
\text { pengurangan } \\
\text { BOD }(\%)\end{array}$ & $\begin{array}{c}\text { BOD } \\
\text { keluar } \\
(\mathbf{m g} / \mathbf{L})\end{array}$ & $\begin{array}{c}\text { TSS } \\
\text { masuk } \\
(\mathbf{m g} / \mathrm{L})\end{array}$ & $\begin{array}{c}\text { Efisiensi } \\
\text { pengurangan } \\
\text { TSS }(\%)\end{array}$ & $\begin{array}{c}\text { TSS } \\
\text { keluar } \\
(\mathbf{m g} / \mathbf{L})\end{array}$ \\
\hline 1,05 & 50 & 0,52 & 59,75 & 50 & 29,87 \\
\hline
\end{tabular}

Efisiensi bak pengendap terhadap penurunan kadar BOD sebesar $50 \%$ dan TSS sebesar 50\%.

Tabel 14. Hasil perhitungan bak pengendap akhir II

\begin{tabular}{ll}
\hline Ketrangan & Nilai Perhitungan \\
\hline Debit air limbah & $7,88 \mathrm{~m}^{3}$ \\
Waktu tinggal dalam bak & $5 \mathrm{jam}$ \\
Volume bak yang diperlukan & $1,7 \mathrm{~m}^{3}$ \\
Dimensi bak pengendap akhir II & $1,7 \mathrm{~m} \times 1 \mathrm{~m} \times 1 \mathrm{~m}$ \\
Tinggi ruang bebas & $0,55 \mathrm{~m}$ \\
Volume efektif & $1,7 \mathrm{~m}^{3}$ \\
Cek waktu tinggal rata-rata & $5 \mathrm{jam}$ \\
Beban permukaan rata-rata & $4,8 \mathrm{~m} \cdot$ hari \\
\hline
\end{tabular}

5. Dimenasi bak IPAL Biofilter Anaerob-Aerob Hasil perhitungan desain maka dimensi bak IPAL biofilter anaerob dapat dilihat pada Tabel 15 . 
Tabel 15. Dimensi bak IPAL biofilter anaerob-aerob

\begin{tabular}{|c|c|c|c|c|c|}
\hline & Tinggi & & & Tinggi & \\
\hline $\begin{array}{c}\text { Unit } \\
\text { Pengolahan }\end{array}$ & $\begin{array}{c}\text { ruang } \\
\text { bebas } \\
(\mathbf{m})\end{array}$ & $\begin{array}{c}\text { Panjang } \\
\text { (m) }\end{array}$ & $\begin{array}{c}\text { Lebar } \\
\text { (m) }\end{array}$ & $\begin{array}{l}\text { kedalaman } \\
\operatorname{air}(\mathbf{m})\end{array}$ & Efisiensi \\
\hline $\begin{array}{l}\text { Bak Kontrol } \\
\text { dengan } \\
\text { penyaring halus } \\
\text { (fine screen) }\end{array}$ & - & 0,45 & 0,40 & 0,40 & TSS $30 \%$ \\
\hline $\begin{array}{c}\text { Bak Pengendap } \\
\text { awal }\end{array}$ & 0,55 & 1,7 & 1 & 1 & $\begin{array}{c}\text { BOD } 40 \% \\
\text { TSS } 60 \%\end{array}$ \\
\hline Biofilter Anaerob & 0,55 & 1 & 0,83 & 1 & $\begin{array}{c}\text { BOD } 80 \% \\
\text { TSS } 60 \%\end{array}$ \\
\hline Biofilter Aerob & 0,55 & 0,8 & 0,53 & 1 & $\begin{array}{c}\text { BOD } 60 \% \\
\text { TSS } 50 \%\end{array}$ \\
\hline $\begin{array}{c}\text { Bak Pengendap } \\
\text { Akhir I }\end{array}$ & 0,55 & 1,7 & 1 & 1 & $\begin{array}{c}\text { BOD } 50 \% \\
\text { TSS } 50 \%\end{array}$ \\
\hline $\begin{array}{c}\text { Bak Pengendap } \\
\text { Akhir II }\end{array}$ & 0,55 & 1,7 & 1 & 1 & $\begin{array}{c}\text { BOD } 50 \% \\
\text { TSS } 50 \%\end{array}$ \\
\hline
\end{tabular}

\section{KESIMPULAN}

Berdasarkan hasil menunjukkan bahwa debit air limbah lods basah Pasar Tradisional Mandonga sebesar 7,88 $\mathrm{m}^{3} \cdot \mathrm{h}^{-1}$. Desain pengolahan menggunakan metode biofilter anaerob aerob yang terdiri dari 6 kompartemen yaitu bak kontrol beserta saringan halus $(3 \mathrm{~mm}$ ) dengan panjang bak sebesar $0,50 \mathrm{~m}$, lebar $0,50 \mathrm{~m}$, dan tinggi $0,40 \mathrm{~m}$, bak pengendap awal yaitu panjang sebesar 1,7 $\mathrm{m}$, lebar $1 \mathrm{~m}$, dan tinggi $1 \mathrm{~m}$, bak biofilter anaerob yaitu panjang sebesar $1 \mathrm{~m}$, lebar $0,83 \mathrm{~m}$ dan tinggi $1 \mathrm{~m}$, bak biofilter aerob yaitu panjang sebesar $0,80 \mathrm{~m}$, lebar $0,53 \mathrm{~m}$ dan tinggi $1 \mathrm{~m}$, bak pengendap akhir I yaitu panjang $1,7 \mathrm{~m}$, lebar $1 \mathrm{~m}$ dan tinggi $1 \mathrm{~m}$, bak pengendap akhir II yaitu panjang $1,7 \mathrm{~m}$, lebar $1 \mathrm{~m}$ dan tinggi $1 \mathrm{~m}$.

\section{UCAPAN TERIMA KASIH}

Ucapan terima kasih kami sampaikan pada Program Studi Teknik Lingkungan atas pelaksanaan penelitian ini.

\section{DAFTAR PUSTAKA}

BPS Sultra, 2020. Provinsi Sulawesi Tenggara Dalam Angka 2020. Kendari - BPS Sultra.

Mega, Isna dan Titin. 2013. Pengolahan Limbah Cair Domestik Dengan Biofilter Aerob Menggunakan Media Bioball Dan Tanaman Kiambang. Pontianak: Universitas Tanjung Pura.

Noerbambang, S. M., \& Morimura, T. 1986. Perancangan dan pemeliharaan sistem plambing. PT. Pradnya Paramita, Jakarta.

Pankratz, Thomas.M. 2017. Screening Equipment Handbook for Industrial and Municipal Water and Wastewater Treathment Second Edition. CRC Press.

Permen LHK. 2016. Peraturan Menteri Lingkungan Hidup Republik Indonesia Tahun 2016.
Republik Indonesia. 2017. Peraturan Menteri Pekerjaan Umum dan Perumahan Rakyat Nomor 04 Tahun 2017.

Said, N.I, Wahyu Widayat. 2019. Perencanaan dan Pembangunan Instalasi Pengolahan Air Limbah Domestik Dengan Proses Biofilter Anaerob-Aerob.Yogyakarta: Gosyen Publishing

Said, N.I. 2017. Teknologi Pengolahan Air Limbah. Jakarta: Erlangga

Standar Nasional Indonesia. 2004. Air dan air limbah - Bagian 3: Cara uji padatan tersuspensi total (Total Suspended Solid, TSS) secara gravimetri,SNI 06-6989.3-2004

Standar Nasional Indonesia. 2008. Air Dan Limbah - Metoda Pengambilan Contoh Air Limbah, SNI 6989.59: 2008.

Standar Nasional Indonesia. 2009. Air dan Limbah - bagian 72 : Cara uji oksigen biokimia (Biochemical Oxygen Demand/BOD), SNI-6989-72_2009 